\title{
Effect of White Mulberry Extract on Performance, Anti-inflammatory and Serum Antioxidant Parameters in Diabetes-induced Rats with Streptozotocin
}

\author{
Zekeriya Safa İNANÇ ${ }^{*}$, Harun KARACA², Volkan İPEK ${ }^{3}$, Burcu Menekşe BALKAN ${ }^{4}$, Orhan ÇORUM ${ }^{5}$, \\ Şükrü GÜNGÖR², Muhammed Enes İNANÇ², Halit İMİK¹, Ayhan ATA² \\ ${ }^{1}$ Department of Animal Nutrition and Nutritional Diseases, Faculty of Veterinary Medicine, University of Atatürk, 25240, Erzurum, Turkey \\ ${ }^{2}$ Department of Reproduction and Artificial Insemination, Faculty of Veterinary Medicine, University of Mehmet Akif Ersoy, 15030, Burdur, Turkey \\ ${ }^{3}$ Department of Pathology, Faculty of Veterinary Medicine, University of Mehmet Akif Ersoy, 15030, Burdur, Turkey \\ ${ }^{4}$ Department of Biochemistry, Faculty of Veterinary Medicine, University of Mehmet Akif Ersoy, 15030, Burdur, Turkey \\ ${ }^{5}$ Department of Pharmacology and Toxicology, Faculty of Veterinary Medicine, University of Kastamonu, 37200, Kastamonu, Turkey
}

\begin{abstract}
This study was conducted to investigate the effect of the white mulberry extract on histopathology, anti-inflammatory properties of liver tissue, blood serum antioxidant parameters and performance parameters of diabetes-induced rats with streptozotocin. Experimental groups consist of 24 animals which were divided into four groups; control group (C, n: 5), streptozotocin applied group 1 (DG 1, n: 6), mulberry extract applied group 2 (DG 2, n: 7), streptozotocin and mulberry extract experimental group 3 (DG 3, n:6), totally 24 animals were used. Although vascular congestion in the liver tissue was detected 2 animals in C and DG 2 groups and 1 animal in DG 3 group, vascular congestion was detected in all animals in DG 1 group. ( $\mathrm{P}<0.05)$. Inflammatory findings of liver tissue were not seen in $\mathrm{C}$, whereas it was mild in 2 animals in DG 2 and it was seen in all animals in the group of DG 1. Degeneration findings in liver tissue were not seen in $\mathrm{C}$, but it was detected in 1 animal of DG 2 and all animals in DG 1 ( $\mathrm{P}<0.01)$. There was no statistical difference between the ceruloplasmin levels of the groups (P>0.05). Live weight gain in control group 150,03 g., DG 2114.43 g. (P <0,01). 1.33 g. live weight gain and weight loss in DG 3 (P> 0.05). In conclusion, mulberry extract applied to rats significantly reduced vascular congestion, inflammation and degeneration findings in liver tissue and it can be said that mulberry extract has antiinflammatory effect.
\end{abstract}

Keywords: Anti-inflammatory, Antioxidant, Inflammation, Performance, White Mulberry Extract.

\section{Streptozotosin ile Diyabet Oluşturulan Ratlarda Beyaz Dut Ekstraktının Performans, Antienflamatuar ve Serum Antioksidan Parametreleri Üzerine Etkisi}

\section{ÖZ}

Bu çalışmada streptozotosin uygulanarak diyabet oluşturulan ratlarda beyaz dut ekstraktının kan serumlarında antioksidan etkileri, karaciğer dokusu histopatoloji, antienflamatuar özelliği ve ratlarda performans parametreleri üzerine etkisi araştırıldı. Deney gruplar1, kontrol grubu (K, n:5), streptozotosin uygulanan deney grubu 1 (DG 1, n:6), dut ekstrakt1 uygulanan deney grubu 2 (DG 2, n:7), streptozotosin ve dut ekstraktının birlikte uygulandığı deney grubu 3 (DG 3, n:6) olmak üzere toplam 24 adet hayvandan oluşturuldu. Karaciğer dokusunun yapısındaki vasküler konjesyon K ve DG 2'de 2 hayvanda, DG 3'te 1 hayvanda tespit edilmesine rağmen, DG 1'de bütün hayvanlarda belirlenmiştir $(\mathrm{P}<0,05)$. Karaciğer dokusunun yang1 bulguları K'da görülmezken, DG 2'de 2 adet hayvanda hafif şekilde, DG 1'deki tüm hayvanlarda gözlenmiştir. Karaciğer dokusundaki dejenerasyon kontrol grubunda görülmezken, DG 2'de 1 adet, DG 1'de ise tüm hayvanlarda görülmüştür (P<0,01). Grupların serum dokularındaki seruloplazmin düzeyleri arasında önemli bir fark bulunmazken $(\mathrm{P}>0,05)$, Paraoksonaz (PON) aktiviteleri arasındaki fark önemli düzeyde olduğu tespit edilmiştir $(\mathrm{P}<0,05)$. Canlı ağılık artışı kontrol grubunda 150,03 g., DG 2 de 114,93g. olarak gerçekleşmiştir $(\mathrm{P}<0,01)$. DG 1'de deneme süresince $1.33 \mathrm{~g}$. canlı ağırlık artış1 olurken DG 3'te ağırlık kaybı olmuştur $(\mathrm{P}>0,05)$. Sonuç olarak araştırmada ratlara uygulanan dut ekstraktının karaciğer dokusunda vasküler konjesyon, yang1 ve dejenerasyon olgularını önemli derecelerde azalttı̆̆ ve antienflamatuar etkisi gösterebileceği söylenebilir.

Anahtar Kelimeler: Antienflamatuar, Antioksidan, Beyaz dut ekstrakt1, Performans, Yang1

To cite this article: Inanc Z.S. Karaca H. Ipek V. Balkan B.M. Corum O. Güngör S. Inanc M. E. Imik H. Ata A. Effect of White Mulberry Extract on Performance, Anti-inflammatory and Serum Antioxidant Parameters in Diabetes-induced Rats with Streptozotocin. Kocatepe Vet J. (2020) 13(1):1-10. 


\section{GİRİŞ}

Günümüzde deney hayvanları birçok amaç için kullanılmaktadır. Bunun en önemli nedeni deney hayvanlarının çok hızlı ve kısa sürede üremesi, gelişmesi ve ekonomik olmasıdır. Ayrıca, ratların metabolizmalarının diğer hayvanlara göre insan metabolizmasına daha yakı olması saylabilir. Hastalıklarla mücadeleyi geliştirmek ve yönetmek için yeni ilaçlar ve etken maddeler üzerine çalışmalar yapılmaktadır. Beyaz dut bitkisi (Morus Alba) gida, ilaç, kozmetik ve hayvancillk sektöründe özellikle ipek böceği beslenmesinde (yaprakları) yaygin olarak kullanılmaktadır (Başkaya 2013).

Canlılar strese maruz kaldıklarında doku hücrelerinde çeşitli hasarlar oluşabilmektedir. Hücrelerde oluşan hasarın derecesi, stresi yapan etkenin kendisi ve dozuna bağlı olarak değişmektedir. Streptozotosin'in (STZ) hayvanların başta pankreas ve karaciğer olmak üzere çeşitli dokusunda hasar oluşturduğu bilinmektedir (Yaman ve Doğan 2016).

Seruloplazmin (SP) büyük oranda karaciğerde sentezlenen, bakırın taşınmasında ve vücutta oluşan oksidatif serbest radikallerin uzaklaştırılmasında önemli görevleri olan bir proteindir. SP, dokularda oluşan hasarları asgariye indirmek için antioksidan ve sitoprotektif özellikler gösteren akut faz bir proteindir (Fox ve ark. 1995, Mcpearson 1996). Bu protein ayn1 zamanda oksidaz enzimi özelliğinde olduğu için (Balakrishnan ve Goswami 1991, Fleming ve ark. 1991) demir metabolizmasında da önemli görevleri bulunmaktadır. Ayrıca hücre dışında diğer antioksidanlar ( $\mathrm{E}$ ve $\mathrm{C}$ vitamini ile albumin, bilirubin, haptoglobulin, beta-karoten ve alfa-I antitripsin, transferrin) ile birlikte savunma sisteminde görev alır (Halliwell 1991). Paraoksonaz enzimi (PON) karaciğerde sentezlenmesine rağmen karaciğer, böbrek, ince bağırsak başta olmak üzere birçok dokuda ve plazmada bulunur. Bu enzimin en önemli görevi hidrojen peroksit radikallerini organizmadan uzaklaştırmak ve yağ asitlerini oksidasyondan korumaktır (Ali ve ark. 2003).

Dünyada tropikal ve subtropikal iklime sahip sicak bölgelerde yetiştirilen beyaz dut bitkisi (Morus Alba) birçok kullanım alanı bulunmaktadır. Bu bitkinin meyvesi değişik formatlarda gida ve medikal sektöründe, yaprakları ise ipek böceği yetiştiriciliğinin yem maddesi olarak geniş alanda kullanılmaktadır. Günümüzde doğal olmayan bazı katkı maddelerinin kullanımına bağlı olarak hastalıkların arttığı ve bu durum ise insanların doğal ürünleri tüketimine yönelmesine neden olmuştur. Ayrıca günümüzde buna paralel olarak, özellikle medikal sektörde doğal ürünlerin kullanım alanı artmıştır. Dut meyvesinin yapisinda bulunan [alkaloidler, flavonoidler (Du ve ark 2003), glikozitler (Katsube ve ark 2006, Wang ve ark 2011), terpenoidler (Kikuchi ve ark 2010), steroidler (Kuo ve ark 1970), uçucu yağlar, tanenler (Banfield 1951)] maddelerin antidiabetik (Singab ve ark 2005), hipolipidemik, antihipertansif (Lee ve ark 2011), antimikrobiyal (Kim ve ark 1993), antioksidan (Arabshahi-Delouee ve Urooj 2007, Wattanapitayakul ve ark 2005), antiteratosklerotik (Enkhmaa ve ark 2005), antikanser (Choi ve Hwang 2005), nöroprotektif (Niidome ve ark 2007) ve antiülser (Ameen ve ark 2009) etkilerinin olduğu bildirilmiştir.

$\mathrm{Bu}$ çalışma streptozotosin (STZ) ile diyabet oluşturulan ratların karaciğer doku ve kan serum örneklerinde analizler yapılmıştır. Yapılan literatür taramasinda dut ekstraktı uygulamasinin STZ ile indüklenen diyabet modelinde etkinliği hakkında herhangi bilgi bulunamamıştır. Hayvanlar diyabet olduklarında pankreas dokusunun hasar görmesi sonucu insülin metabolizmasının bozulduğu bilinmektedir. Bu çalışmanın yapılma amacı, STZ ve dut ekstraktı uygulamasının karaciğer dokusunun histopatolojisi, performans parametreleri ve serumlarında antioksidan parametreleri üzerine etkilerini araştırmaktır.

\section{MATERYAL ve METOT}

Hayvan ve Yem Materyali, Bakımı ve Beslenmesi Bu çalşma Mehmet Akif Ersoy Üniversitesi Veteriner Fakültesi Deney Hayvanları Ünitesi’nde 15.05.2019 tarih 522 sayilı etik kurul izni ile yapildı. Deneyde ortalama 8 haftalık yaşta 24 adet erkek Wistar Albino 1rkı rat kullanıldı. Deneme başında ratların ortalama canlı ağırlıkları Hayvanlara günlük 12 saat ışık ve 12 saat karanlık olacak şekilde, yaklaşık $20 \pm 2^{\circ} \mathrm{C}$ sıcaklık ve nem oranı $\% 45-65$ olan bir ortam sağlandi. Hayvanlara verilecek olan rasyon özel bir yem fabrikasından temin edildi. Hayvanların beslenmesinde kullanilan yemin besin madde kompozisyonu ham proteini $\% 24$, ham yağ1 $\% 3$, ham selülozu \%5,97, metabolik enerjisi $3300 \mathrm{kcal} / \mathrm{kg}$ olacak şekilde dizayn edildi (Bazal rasyon, NRC 1995). Hayvanlara yem ve su ad libitum sağlandi.

\section{Dut Ekstraktının Hazırlanması}

$\mathrm{Bu}$ çalş̧mada kurutulmuş beyaz dut meyvesinin (white mulberry fruits, Morus alba) ekstraktı kullanıldı. Beyaz dut meyvesi ise Erzincan iline bağlı Yeşilçay köyünden (Türkiye, 3943'14.3"K $39^{\circ} 21^{\prime} 28.8^{\prime \prime D}$ ) temin edildi. Kurutulmuş dut meyve ekstraktı elektrikli değirmende ögütülüp $0.5 \mathrm{~mL}$ 'lik eleklerden geçirilip 1şıktan etkilenmemesi için kahverengi cam kavanozlara alındı. Dutun methanolik ekstraktının elde edilmesinde Alam ve ark (2002) ve Khan ve ark (2013) tarafindan bildirilen yöntem kullanıldı. Bu yönteme göre yaklaşı olarak ögütülmüş 500 gr. dut meyvesi kahverengi şişelere alınıp üzerine $1.5 \mathrm{~L}$ methanol eklendi. Bu karışım 15 gün boyunca, her 12 saatte bir 1'er saat çalkalayıcı kullanılarak çalkalandı. Dut meyvesi-methanol karışımı Watman süzgeç kâğıdı kullanılarak steril kaba süzülüp, kullanıma hazır hale getirmek için $50^{\circ} \mathrm{C}$ basınçta vakumlu evaporator 
kullanılarak çözücünün uçması sağlandı ve dut ekstraktı elde edildi. Ekstrakt tartılarak içme suyu ile çözdürülerek ratlara uyguland1.

\section{Diyabet Oluşturulması}

Taze sitrat tamponu bir miktar saf suda 2,1 g sitrik asit monohidrat (C6H8O7 . H2O) çözdürülüp üzerine 2,94 g trisodyum sitrat dihidrat (C6H5Na3O7 - 2H2O) eklenerek son hacim 100 mL'ye tamamlandiktan sonra Inolab WTW pH metre kullanilarak pH 4,5'e ayarland1( Türkmen 2013). Hazırlanan sitrat tamponunda çözdürülen STZ (40 $\mathrm{mg} / \mathrm{kg}$ ) subkutan olarak üç gün ara ile iki doz şeklinde yapıldı. Ratlarda, ilaca bağlı hipoglisemik şoku engellemek için 24 saat süre ile $\% 5$ glikoz solüsyonu içme suyu ile verildi. Bir hafta sonra açlık kan kan glikoz seviyesi $\geq 300 \mathrm{mg} / \mathrm{dL}$ seviyesinin üzerinde olan hayvanlar diyabetik olarak kabul edildi (Dik ve ark. 2017).

\section{Deney Gruplarının Oluşturulması}

Hayvanlar ortalama 8 haftalık yaşa geldiklerinde gruplar oluşturuldu. Oluşturulan gruplara aşağıdaki uygulamalar yapildi.

Kontrol grubu ( $K, \mathrm{n}: 5)$ : Bazal rasyon verildi. İlave olarak 56 günlük deneme süresince oral gastrik gavaj yöntemiyle $0,5 \mathrm{ml}$ içme suyu verildi.

Deney Grubu 1 (DG 1, n:6): Ratlara çalışma başlangıcında ayr1 ayrı subkutan $(40 \mathrm{mg} / \mathrm{kg}) 3$ gün ara ile 2 doz STZ (STZ- \%98 HPLS, Sigma-Aldirich Co., USA) uygulandi. Bazal rasyona ilave olarak 56 günlük deneme süresince oral gastrik gavaj yöntemiyle $0,5 \mathrm{ml}$ içme suyu verildi.

Deney Grubu 2 (DG 2, n:7): Bazal rasyona ilave olarak her hayvana 56 günlük deneme süresince oral gastrik gavaj yöntemiyle $600 \mathrm{mg} / \mathrm{kg}(0,5 \mathrm{ml})$ doz olarak dut ekstraktı verildi

Deney Grubu 3 (DG 3, n:6): Ratlara çalışma başlangıcında ayrı ayrı subkutan $(40 \mathrm{mg} / \mathrm{kg}) 3$ gün ara ile 2 doz STZ ve Bazal rasyona ilave olarak 56 günlük deneme süresince oral gastrik gavaj yöntemiyle $600 \mathrm{mg} / \mathrm{kg}(0,5 \mathrm{ml})$ dut ekstraktı verildi.

Araştırma gruplarının canlı ağırlıkları deneme başından itibaren her hafta düzenli olarak alındı. Hayvanlar her hafta aynı gün yemlemeden önce (aç karınlarına) tartılarak canlı ağırlıkları belirlendi. Yem ve su tüketimleri ile ilgili veriler, araştırmanın 3 . haftasindan sonra her sabah saat 08:30 da alındi. Her sabah hayvanların yemliklerinde artan yemler tartılip, su miktarı ölçülüp kaydedildi ve yerine tekrar tartılarak ve ölçülerek konuldu. Daha önce dut ekstraktı ile yapılmış çalışma bulunmadığ1 için bu araştırmada kullanılacak doz $(600 \mathrm{mg} / \mathrm{kg})$, daha önce dut yaprakları ile yapılmış çalışmadan seçildi (Omar ve ark. 2016). 56 günlük deneysel prosedürün sonunda ratlar ksilazin $(10 \mathrm{mg} / \mathrm{kg}$, periton içi, Ksilazol, Provet, Türkiye) - ketamin (60 mg/kg, periton içi, Ketalar, Pfizer, ABD) anestezisi altında iken kalplerinden kan alınıp servikal dislokasyon yöntemiyle ötenazi edildi ve karaciğer ağırlıkları tespit edildi.

\section{Biyokimyasal ve Histopatolojik Analizler}

Ratlardan alınan kan örnekleri 2500 rpm'da 10 dakika santrifüj edilerek elde edilen serum örneklerinden SP ve PON analizleri gerçekleştirildi. SP düzeyleri Ceron ve Suibela-Martinez (2004) tarafindan bildirilen yöntemle ölçüldü. Yöntemde laboratuvar şartlarında manuel olarak hazırlanan asetat tamponunda(0,6 M $\mathrm{CH}_{3} \mathrm{COONa}$. $3 \mathrm{H}_{2} \mathrm{O}$, pH 5.0) P-fenilen diamin diklorid (PPD)'e serum örnekleri eklendi ve oluşan rengin absorbansin 550 nm'de spektrometrik olarak ölçülerek elde edilen absorbanslardan serum seruloplazmin değeri hesaplandi (Curzon ve ark. 1960). PON aktivitesi ise Armstrong (2008) tarafindan bildirilen yöntemle ölçüldü. Bu yöntemle, 1 $\mathrm{mM} \mathrm{CaCl} 2$ ve $4 \mathrm{mM}$ paraokson içeren $50 \mathrm{mM}$ laboratuvar şartlarında hazırlanan glisin tampon ( 50 $\mathrm{mM}$ Glisin, $1 \mathrm{mM} \mathrm{CaCl}$, $\mathrm{pH} 10.5,37^{\circ} \mathrm{C}$ ) kullanılarak, PON enzimatik olarak hidroliz edilip ve p-nitrofenol oluşturuldu. Oluşan rengin absorbansı 412 nm ölçülerek PON aktiviteleri hesaplandi.

Alınan kan örneklerinden elde edilen serumlarda SP ve PON antioksidan analizleri yapıldı. Karaciğer dokular1 \%10'luk tamponlu formaldehitte tespit edildikten sonra rutin takip prosedüründen geçirilerek parafine gömüldü ve $5 \mu \mathrm{m}$ kalınlığında kesitler alınarak hematoksilen-eozin ile boyanarak belirlendi (Taylor ve Cote 1994). Histopatolojik değerlendirme amaciyla vasküler konjesyon (VK), yang1 (Y), dejenerasyon (D), nekroz $(\mathrm{N})$, kanama $(\mathrm{K})$, safra kanalı hiperplazisi $(\mathrm{SKH})$ ve fibrosis (F) varlığ1 gruplar arasında karşılaştırıldı ve 1şık mikroskobu (Nikon Eclipse E600) ile değerlendirildi.

Histopatolojik olarak lezyon skorlanması yar1 kantitatif yöntemle 40X magnification mikroskop (Nikon Eclipse E600, Japonya) altında 10 farklı alan incelenerek değerlendirildi. Skorlama: - (yok), + (hafif), ++ (orta) ve +++ (şiddetli) olarak yapıld1.

Kan örnekleri 2500 rpm' de 10 dakika santrifüj edildi. Elde edilen serum örneklerinde SP ve PON analizleri gerçekleştirildi.

\section{İstatistiksel Analizler}

Araştırmada elde edilen bulguların istatiksel değerlendirilmesinde SPSS paket programı kullanıld1. Çalışmada elde edilen bulgulardan canlı ağırlık artışı, karaciğer ağırlı̆̆1, serum SP ve PON seviyelerinin analizinde, istatistiksel değerlendirilmesinde Tek yönlü ANOVA, gruplar arasındaki önemliliği belirlemek için post-hoc olarak Duncan testi kullanılmıştır. Karaciğerdeki histopatolojik değişimlerin (VK, Y ve D) hesaplanmasinda ise Kruskal- Wallis analizi yapılmıştır. Tablolarda veriler $\mathrm{X} \pm$ standart hata 
șeklinde ifade edilmiș, önemlilik düzeyi $(\mathrm{P}<0.05$ olarak belirlenmiştir). Çalışmada yem tüketimi ve su tüketimi ile ilgili hesaplamalarda ise istatistik analiz yapılmayıp matematiksel olarak hesaplanmıştır (SPSS 2011).

\section{BULGULAR ve TARTIŞMA}

Günümüzde hayvan deneylerinde diyabet oluşturmak için STZ uygulaması yoğun olarak kullanılmaktadır. STZ organizmada serbest radikal olarak etki göstererek dokularda birçok hasara neden olmaktadır. En fazla etkilenen dokuların başında pankreas ve karaciğer gelmektedir (Kurçer ve Karaoğlu 2012). Diyabet olan canliların organizmalarında ve metabolizmalarında önemli değişimler olmaktadır. Bu değişimler kendini başta pankreas dokusunda göstermektedir. Pankreas dokusundaki değişimlerin insülin metabolizmasını etkilediği bilinmektedir. Diğer taraftan karaciğer dokusu ise bu tür etkenlerin (serbest radikallerin) detoksifiye edildiği en önemli organlardan biridir (Take ve ark. 2004). Bu çalışmada diyabet oluşturulan ratlarda karaciğer dokusunda histopatolojik yap1 ve kan serumunda SP düzeyi ve PON enzimi aktivitesi üzerine etkileri incelenmiştir. Araştırmada hayvanların karaciğer dokusunda oluşan $\mathrm{VK}, \mathrm{Y}, \mathrm{D}, \mathrm{N}, \mathrm{H}, \mathrm{SKH}$ ve $\mathrm{F}$ incelenmiș ve 0 (etkisi yok) ile +3 (Şiddetli) arasında skorlama yapılarak belirlenmiştir.

Karaciğer dokusunun analizinde; safra kanal hiperplazisi ve fibrozis bulguları çalışmada kullanılan gruplardaki hayvanların hiçbirinde görülmemiştir. Hemoraji bulgusu DG 1 ve DG 3 'te sadece birer adet hayvanda, nekroz bulgusu ise sadece DG 1'deki 1 hayvanda görülmüştür (Tablo 1-2). Bu nedenle yukarnda belirttiğimiz bulgular ile ilgili istatistiksel değerlendirme yapılmamıştır.

Karaciğer dokusunda yapısındaki vasküler konjesyon $\mathrm{K}$ ve DG 2'de 2 adet hayvan, DG 3'te 1 adet hayvanda tespit edilmesine rağmen, diyabet yapılan DG 1'de bütün hayvanlarda belirlenmiştir $(\mathrm{P}<0,05)$ (Tablo 1-2). Elde edilen bulguları bütün olarak değerlendirdiğimizde STZ karaciğgerde vasküler konjesyona neden olduğu, ancak dut ekstraktının ise STZ kimyasal ajanın sebep olduğu VK bulgusunu önemli derecede düşürdüğü tespit edilmiştir $(\mathrm{P}<0.05)$ (Tablo 2). Karaciğer dokusunun yang1 parametresi incelendiğinde K'da görülmezken, DG 2'de 2 adet hayvanda hafif şekilde portal alanlarda, DG 1'de ise gruptaki tüm hayvanlarda görülmüss olup; bunlardan bir tanesinde parankimyal yangı belirgin iken, üç hayvanda portal bölgede orta dereceli yangiya ve üç hayvanda ise hafif dereceli portal yangiya rastlanmıştır. DG 3'te ise yalnızca 2 hayvanda hafif dereceli portal yangıya rastlanmıştır (Tablo1, Şekil 6). Karaciğer dokusunun histopatolojik incelenmesinde STZ uygulaması yang1yı önemli derecede yükseltirken, dut ekstraktının yangının baskılanmasında önemli etkisinin olduğu görülmüştür $(\mathrm{P}<0.01) \quad$ (Tablo2). Deney gruplarının karaciğer dokusundaki dejenerasyon bulgular1 incelendiğinde K'da görülmediği, DG 2'de 1 adet hayvanda, DG 1'de ise tüm hayvanlarda görüldüğü belirlenmiştir $(\mathrm{P}<0.01)$ (Tablo 2). DG 3'te dejenerasyon üç olguda hafif şiddette gözlenmiştir. Vakuoler dejenerasyonların çoğunlukla sentrilobuler alanlarda olup, şiddetli vakuolizasyonların gözlendiği DG 1'deki bir olguda ise sentrilobuler alanlarla birlikte midzonal ve periportal alanlarda olduğu görülmüştür (Şekil-5). Dut ekstraktının karaciğerde şekillenen dejenerasyonu önemli derecede düzelttiği ancak tüm hayvanlarda meydana gelen hasar1 tamamen gideremediği tespit edilmiştir (Tablo 1). Dut ekstraktı karaciğer dokusundaki vasküler konjesyon, yang1 ve dejenerasyonu önemli derecede azaltmıştır. Bu durum dut ekstraktının antienflamatuar etkisinin olduğunu belirtebilir.

Araştırma gruplarının serum SP düzeyleri ve PON aktiviteleri Tablo 3'de verilmiştir. Grupların SP miktarı arasında istatistiksel farkl1lik bulunmazken $(\mathrm{P}>0,05)$, PON aktiviteleri arasındaki farklilikların önemli derecede olduğu belirlenmiştir $(\mathrm{P}<0,05)$. PON aktivitesi en yüksek K'da görülürken, en düşük DG 3'de șekillenmiștir. Literatür bilgilerinde dut ekstraktının antioksidan özellikleri olduğu bildirilmektedir (Arabshahi-Delouee ve Urooj 2007, Wattanapitayakul ve ark 2005). Bu çalışmada SP seviyesinin değişmemesinin literatür bulgularla benzerlik göstermemesi, literatür bilgilerinde genellikle total antioksidan ölçümleri yapıldığından ileri gelebilir. Bu çalışmada ise spesifik bir antioksidan madde olan SP seviyesi tespit edilmiştir. Diğer taraftan PON aktivitesinin dut ekstraktı verilen grupta düşük bulunması, dut ekstraktının bu enzimi aktive ederek kullanımını artırmasına bağlanabilir. $\mathrm{Bu}$ bilgilerden dut ekstraktının antioksidan özelliğinin sınırlı düzeyde olduğu belirtilebilir.

Deneme gruplarınin performans parametrelerinde canlı ağırlık değişimleri Şekil 4 ve Tablo 4'te, yem tüketimleri Şekil 3'te, su tüketimleri Şekil 2' de verilmiştir. Canlı ağırlık artışı en iyi $\mathrm{K}$ ve DG 1'de görülmesine rağmen $(\mathrm{P}<0,01)$, STZ verilen gruplarda önemli derecede düşük bulunmuştur. Yem ve su tüketimi ise tam tersine, STZ verilen gruplarda önemli derecede yüksek bulunurken, verilmeyen gruplarda araştırma süresince fazla bir değişim izlenmemiştir. Streptozotosin özellikle hayvanlarda insülin salınımını azalttığı için katabolizmanın artmasına, enerji açığının kapatılması amaciyla yağ ve protein yıkımına, dolayısıyla kilo kaybina neden olmaktadır (Demirel 2008). Bu çalıșmada da hayvanların besin ihtiyaçlarını karşılamak için daha fazla yem ve su tüketmesine rağmen kilo alamaması, insülin direncine bağlanabilir. Çalışmanın sonunda karaciğer ağırlıkları Şekil 1'de verilmiştir. Nitekim en yüksek karaciğer ağırlığı, en fazla canlı ağırlığa sahip olan K'da şekillenmiştir. 
Buradan canlı ağırlık ile karaciğer ağırlı̆̆1 arasında doğru ilişki olduğu belirtilebilir.

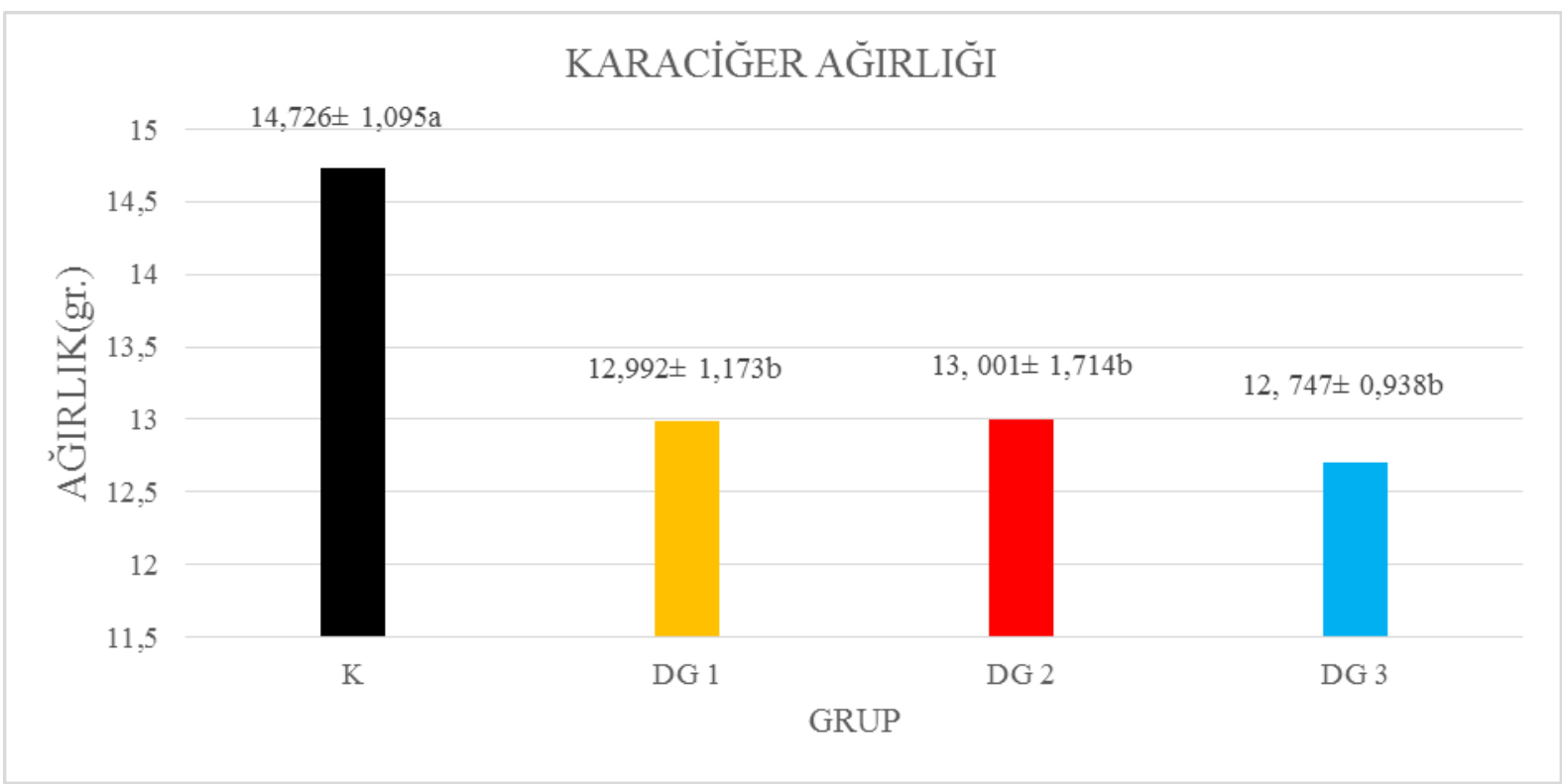

Şekil 1. Grupların deneme sonu karaciğger ağırlı̆ı̆ (gr.)

Figure 1. End-trial liver weight of experimental groups (g.)

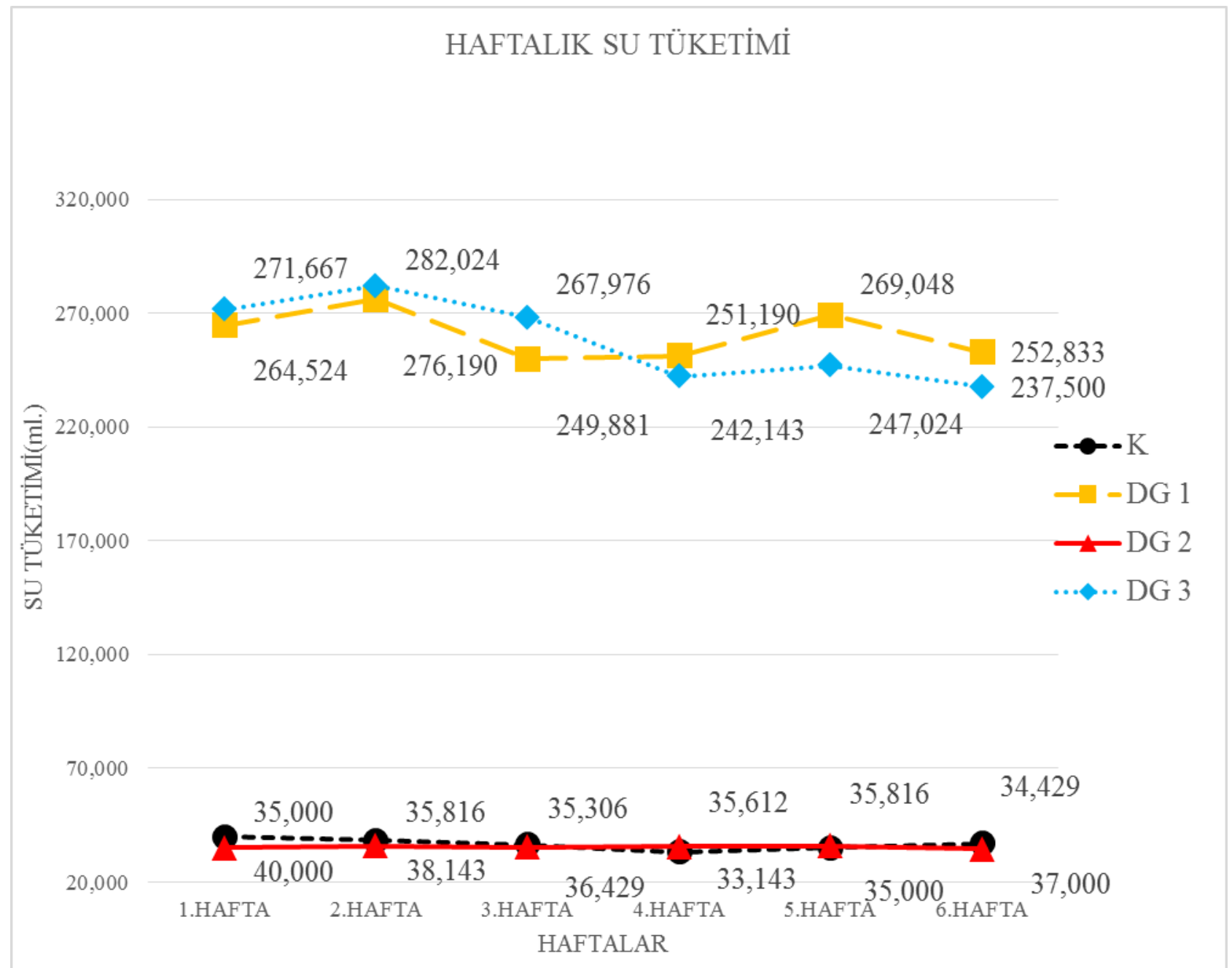

Şekil 2. Gruplarının ortalama su tüketimi (ml.)

Figure 2. Average water consumption of trial groups (ml.) 


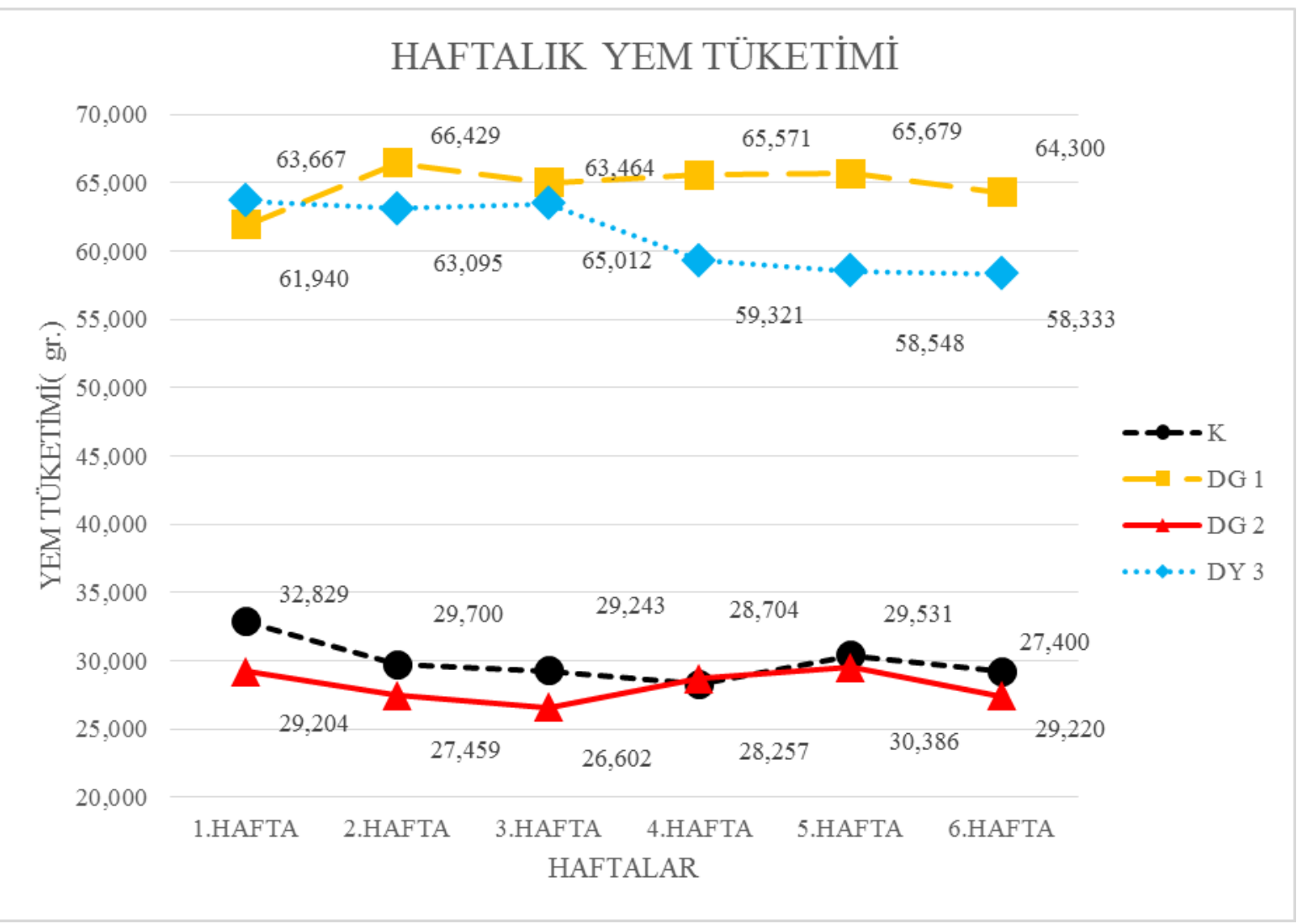

Şekil 3. Gruplarının ortalama yem tüketimi (gr.)

Figure 3. Average feed consumption of groups (g.)

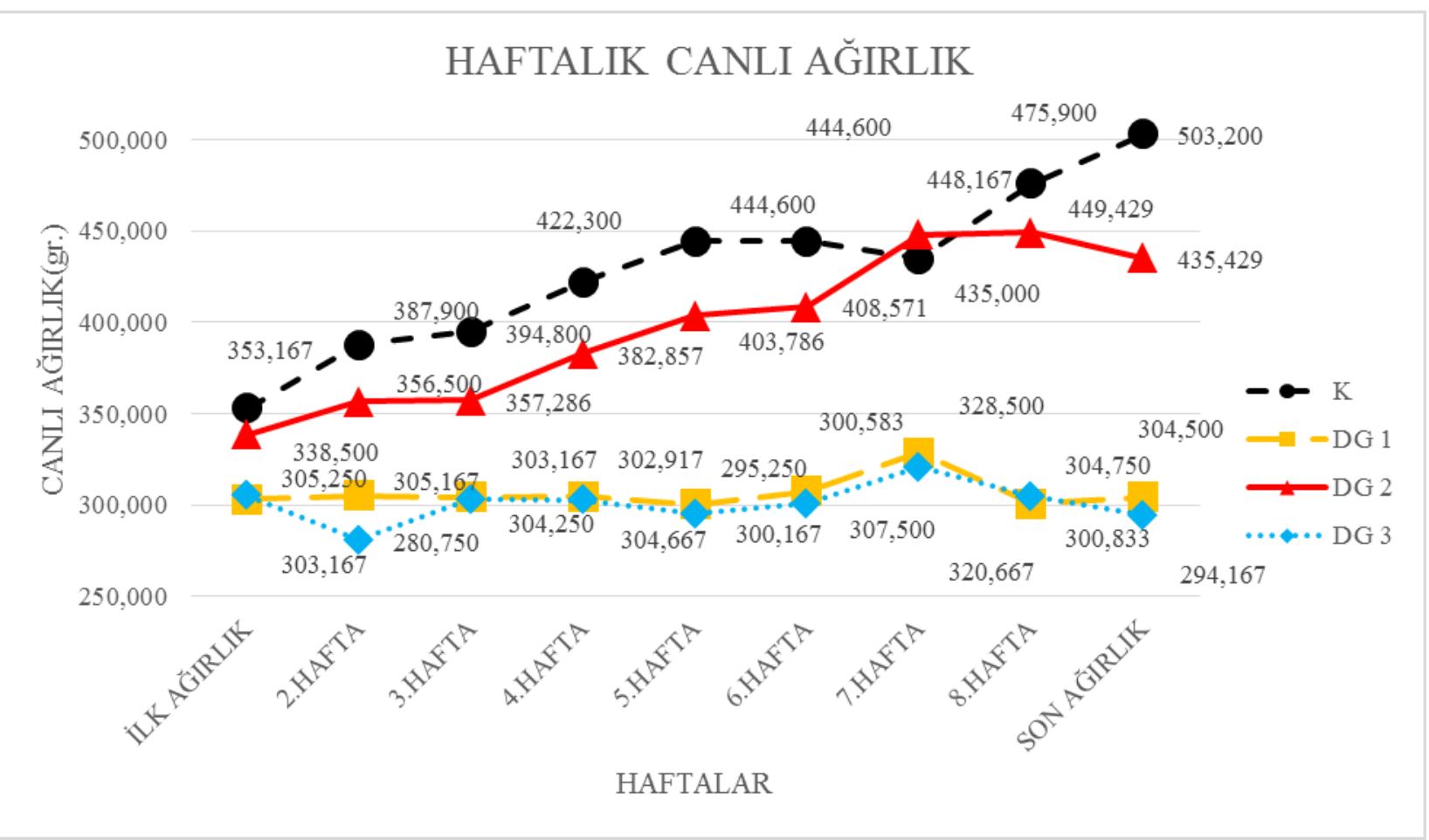

Şekil 4. Gruplarının ortalama canlı ağırlıkları(gr.)

Figure 4. Average live weights of groups (g.) 

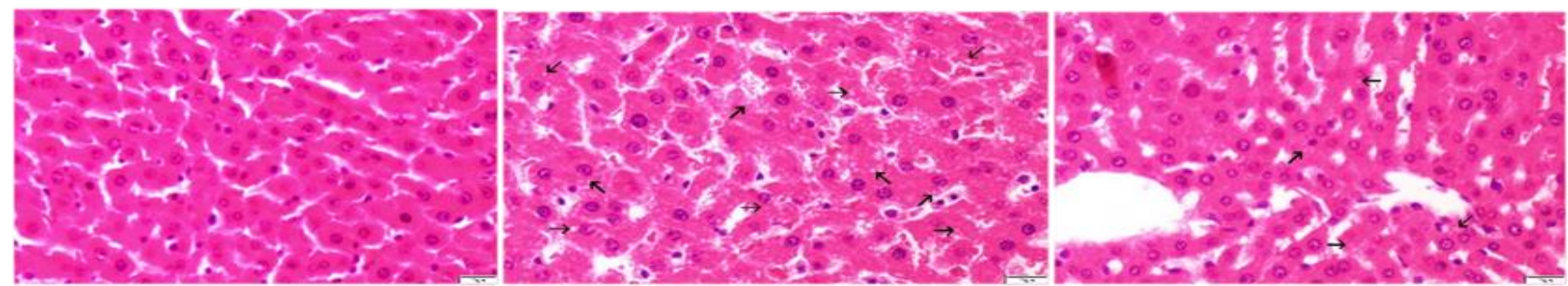

Şekil 5. K grubunda hepatositlerde vakuolizasyon yok (sol), bar $20 \mu \mathrm{m}$; DG 1'de şiddetli vakuolizasyonlar (oklar) (orta), bar $20 \mu \mathrm{m}$; DG' 3'te hafif vakuolizasyonlar (oklar), bar $20 \mu \mathrm{m}, \mathrm{H} \& \mathrm{E}$.

Figure 5. There is no any vacuolization in C (left), bar $20 \mu \mathrm{m}$; severe vacuolizations (arrows) in EG 1(middle), bar $20 \mu \mathrm{m}$; and mild vacuolizations (arrows) in EG 3 (right), bar $20 \mu \mathrm{m}, \mathrm{H} \& \mathrm{E}$.
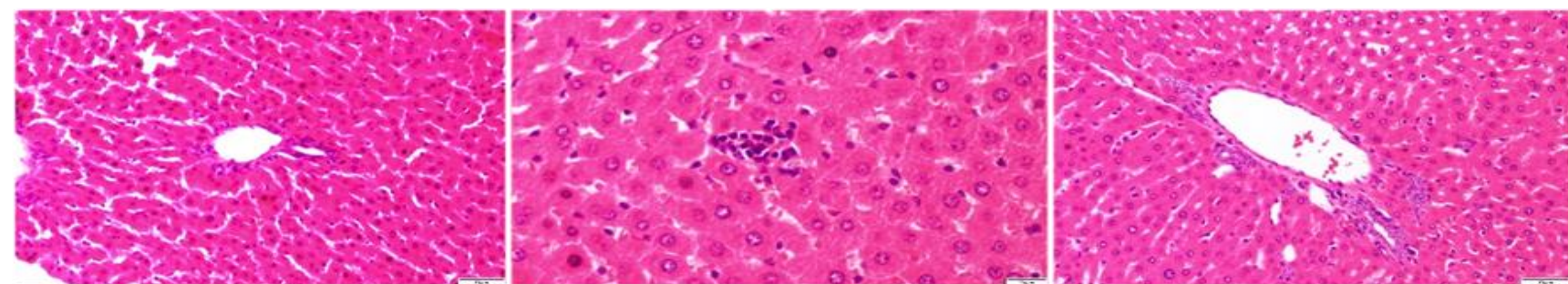

Şekil 6. K'de yang1 yok (sol), bar $50 \mu \mathrm{m}$; DG 1'de hafif parankimal yang1 (orta), bar $20 \mu \mathrm{m}$; ve DG 3'te yang1 yok (sağ), bar $50 \mu \mathrm{m}, \mathrm{H} \& \mathrm{E}$.

Figure 6. Inflammation absent in C (left), bar $50 \mu \mathrm{m}$; mild inflammation in EG 1 (middle), bar $20 \mu \mathrm{m}$; and absent to mild inflammation in EG 3 (right), bar $50 \mu \mathrm{m}, \mathrm{H} \& \mathrm{E} .0 \mathrm{t}$

Tablo 1. Grupların karaciğer dokusunun histopatolojik sonuçlarının skorlanması

Table 1. Scoring of histopathological results of liver tissue of groups

\begin{tabular}{llllllll}
\hline GRUPLAR & \multicolumn{7}{c}{ PARAMETRELER } \\
\hline & VK & Y & D & N & H & SKH & F \\
\hline Kontrol Grubu(K) & & & & & & & \\
\hline $\mathbf{1}$ & 0 & 0 & 0 & 0 & 0 & 0 & 0 \\
$\mathbf{2}$ & +1 & 0 & 0 & 0 & 0 & 0 & 0 \\
$\mathbf{3}$ & 0 & 0 & 0 & 0 & 0 & 0 & 0 \\
$\mathbf{4}$ & +1 & 0 & 0 & 0 & 0 & 0 & 0 \\
$\mathbf{5}$ & 0 & 0 & 0 & 0 & 0 & 0 & 0 \\
\hline Deney Grubu 1(DG 1) & & & & & & & \\
\hline $\mathbf{1}$ & +1 & +2 & +1 & 0 & 0 & 0 & 0 \\
$\mathbf{2}$ & +1 & +1 & +3 & 0 & 0 & 0 & 0 \\
$\mathbf{3}$ & +1 & +1 & +1 & 0 & 0 & 0 & 0 \\
$\mathbf{4}$ & +2 & +2 & +1 & 0 & 0 & 0 & 0 \\
$\mathbf{5}$ & +1 & +1 & +1 & 0 & +1 & 0 & 0 \\
$\mathbf{6}$ & +1 & +2 & +1 & +1 & 0 & 0 & 0 \\
\hline Deney Grubu 2(DG 2) & & & & & & & \\
\hline $\mathbf{1}$ & +1 & 0 & 0 & 0 & 0 & 0 & 0 \\
$\mathbf{2}$ & +1 & 0 & +1 & 0 & 0 & 0 & 0 \\
$\mathbf{3}$ & 0 & 0 & 0 & 0 & 0 & 0 & 0 \\
$\mathbf{4}$ & 0 & 0 & 0 & 0 & 0 & 0 & 0 \\
$\mathbf{5}$ & 0 & 0 & 0 & 0 & 0 & 0 & 0 \\
$\mathbf{6}$ & 0 & +1 & 0 & 0 & 0 & 0 & 0 \\
$\mathbf{7}$ & +1 & 0 & 0 & 0 & 0 & 0 \\
\hline Deney Grubu 3(DG 3) & & & & & & & \\
\hline $\mathbf{1}$ & 0 & +1 & +1 & 0 & 0 & 0 & 0 \\
$\mathbf{2}$ & 0 & +1 & +1 & 0 & 0 & 0 & 0 \\
$\mathbf{3}$ & 0 & 0 & +1 & 0 & 0 & 0 & 0 \\
$\mathbf{4}$ & +1 & 0 & 0 & 0 & +1 & 0 & 0 \\
$\mathbf{5}$ & 0 & 0 & 0 & 0 & 0 & 0 & 0 \\
$\mathbf{6}$ & 0 & 0 & 0 & 0 & 0 & 0 & 0 \\
\hline
\end{tabular}

VK: Vasküler konjesyon, Y:yang1, D: dejenerasyon, N: nekroz, H: hemoraji, SKH :Safra kanal hiperplazisi, F: fibrozis 
Tablo 2. Gruplarının karaciğger histopatolojik verilerinin istatistiksel değerleri

Table 2. Statistical values of liver histopathological data of groups

PARAMETRELER

\begin{tabular}{lcccccc}
\hline & \multicolumn{2}{c}{ Vasküler Konjesyon } & \multicolumn{2}{c}{ Yang1 } & \multicolumn{2}{c}{ Dejenerasyon } \\
\cline { 2 - 7 } K & \multicolumn{1}{c}{$\mathbf{X} \pm$ SH } & Median & $\mathbf{X} \pm$ SH & Median & X \pm SH & Median \\
\cline { 2 - 7 } & $0,400 \pm 0,245^{\mathrm{b}}$ & 0,000 & $0 \pm 0^{\mathrm{b}}$ & 0 & $0 \pm 0,0^{\mathrm{b}}$ & 0,000 \\
DG 1 & $1,167 \pm 0,167^{\mathrm{a}}$ & 1,000 & $1,500 \pm 0,224^{\mathrm{a}}$ & 1,500 & $1,330 \pm 0,333^{\mathrm{a}}$ & 1,000 \\
DG 2 & $0,286 \pm 0,184^{\mathrm{b}}$ & 0,000 & $0,286 \pm 0,184^{\mathrm{b}}$ & 0,000 & $0,143 \pm 0,143^{\mathrm{b}}$ & 0,000 \\
DG 3 & $0,167 \pm 0,167^{\mathrm{b}}$ & 3,000 & $0,333 \pm 0,211^{\mathrm{b}}$ & 0,000 & $0,500 \pm 0,224^{\mathrm{b}}$ & 0,500 \\
\hline P değeri & $*$ & \multicolumn{3}{c}{$* *$} & & $* *$ \\
\hline
\end{tabular}

a,b : Aynı satırda farklı harfi taşıyan ortalamalar arası istatistiki fark anlamlıdır.

$* * \mathrm{P}<0.01, * \mathrm{P}<0.05$

Tablo 3. Gruplarının serum antioksidan parametreleri

Table 3. Serum antioxidant parameters of groups

\begin{tabular}{lcc}
\multirow{2}{*}{ GRUPLAR } & \multicolumn{2}{c}{ PARAMETRELER(Unit/ml) } \\
\cline { 2 - 3 } & Seruloplazmin & Paraoksonaz \\
& $\mathbf{X} \pm \mathbf{S H}$ & $\mathbf{X} \pm \mathbf{S H}$ \\
\cline { 2 - 3 } K & $2,349 \pm 0,549$ & $48,340 \pm 10,405^{\mathrm{a}}$ \\
DG 1 & $2,342 \pm 0,410$ & $40,433 \pm 10,986^{\mathrm{ab}}$ \\
DG 2 & $2,109 \pm 0,580$ & $43,260 \pm 12,362^{\mathrm{ab}}$ \\
DG 3 & $2,540 \pm 0,723$ & $33,102 \pm 13,829 \mathrm{~b}$ \\
\hline P deg
\end{tabular}

a,b : Aynı satırda farklı harfi taşıyan ortalamalar arası istatistiki fark anlamlıdır

$*(\mathrm{P}<0.05)$. NS: $\mathrm{P}>0.05$

Tablo 4. Grupların canlı ağıllık değişimleri (gr.)

Table 4. Live weight changes of groups (g.)

\section{ZAMAN GRUPLAR}

\begin{tabular}{llllll} 
& $\mathbf{K}$ & $\mathbf{D G} \mathbf{1}$ & $\mathbf{D G} \mathbf{2}$ & $\mathbf{D G ~ 3}$ \\
& $\mathbf{X} \pm \mathbf{S H}$ & $\mathbf{X} \pm \mathbf{S H}$ & $\mathbf{X} \pm \mathbf{S H}$ & $\mathbf{X} \pm \mathbf{S H}$ & \\
\cline { 2 - 5 } Deneme Baş1 & $353,17 \pm 29,77$ & $303,167 \pm 41,33$ & $338,50 \pm 30,58$ & $305,25 \pm 34,79$ & NS \\
1.Hafta & $387,90 \pm 19,54^{\mathrm{a}}$ & $305,17 \pm 45,52^{\mathrm{b}}$ & $356,50 \pm 37,58^{\mathrm{a}}$ & $280,75 \pm 26,97^{\mathrm{b}}$ & $* *$ \\
2.Hafta & $394,80 \pm 20,68^{\mathrm{a}}$ & $304,25 \pm 42,74^{\mathrm{b}}$ & $357,29 \pm 41,39^{\mathrm{a}}$ & $303,17 \pm 31,69^{\mathrm{b}}$ & $* *$ \\
3.Hafta & $422,30 \pm 19,45^{\mathrm{a}}$ & $304,67 \pm 37,56^{\mathrm{b}}$ & $382,86 \pm 42,98^{\mathrm{a}}$ & $302,91 \pm 40,74^{\mathrm{b}}$ & $* *$ \\
4.Hafta & $444,60 \pm 22,77^{\mathrm{a}}$ & $300,17 \pm 37,04^{\mathrm{b}}$ & $403,79 \pm 44,67^{\mathrm{a}}$ & $295,25 \pm 34,49^{\mathrm{b}}$ & $* *$ \\
5.Hafta & $444,60 \pm 22,77^{\mathrm{a}}$ & $307,50 \pm 35,37^{\mathrm{b}}$ & $408,57 \pm 47,78^{\mathrm{a}}$ & $300,58 \pm 37,99^{\mathrm{b}}$ & $* *$ \\
6.Hafta & $451,70 \pm 19,94^{\mathrm{a}}$ & $303,25 \pm 29,25^{\mathrm{b}}$ & $429,86 \pm 46,29^{\mathrm{a}}$ & $303,17 \pm 37,13^{\mathrm{b}}$ & $* *$ \\
7.Hafta & $475,90 \pm 23,00^{\mathrm{a}}$ & $300,83 \pm 28,19^{\mathrm{b}}$ & $449,43 \pm 47,57^{\mathrm{a}}$ & $304,75 \pm 38,15^{\mathrm{b}}$ & $* *$ \\
Deneme Sonu & $503,20 \pm 14,86^{\mathrm{a}}$ & $304,50 \pm 33,22^{\mathrm{c}}$ & $435,43 \pm 87,45^{\mathrm{b}}$ & $294,17 \pm 37,46^{\mathrm{c}}$ & $* *$ \\
\hline
\end{tabular}

a,b,c : Aynı satırda farklı harfi taşıyan ortalamalar arası istatistiki fark anlamlıdır.

NS: $\mathrm{P}>0.05, * *: \mathrm{P}<0.01$ 


\section{SONUÇ}

Araştırmada ratlarda STZ ile indüklenen diyabet modelinde karaciğer dokusunda vasküler konjesyon, yang1 ve dejenerasyonun önemli derecede artırdığ1, dut ekstraktı uygulamasinin ise antienflamatuar özelliklerinden dolayı bu histopatolojik değişiklikleri önemli derecede azalttığ1 tespit edildi. Ayrıca dut ekstraktını diyabete bağlı olarak azalan PON düzeyini artırarak sınırlı derecede antioksidan etki gösterdiği belirlendi. STZ uygulanan hayvanlara verilen dut eksraktının hepatoselüler dejenerasyonu azaltmasının nedeni de antioksidan etki ile ilişskili olabilir. Ancak dut ekstraktının antioksidan ve antienflamatuar özelliklerinin ortaya konulması için daha kapsamlı çalışmalara ihtiyaç vardır.

\section{TEŞEKKÜR}

Mehmet Akif Ersoy Üniversitesi Hayvan Deneyleri Yerel Etik Kurulu (15.05.2019/522).

Çıkar Çatışması: Yazarlar, çıkar çatışması olmadığını beyan eder.

\section{KAYNAKÇA}

Alam AHMK, Rahman MAA, Baki MA, Rashid MH, Bhuyan MSA, Sadik G. Antidiarrhoeal principle of Achyranthes ferruginea Roxb. and their cytotoxicity. Pharm. J. 2002; 12: 1-4.

Ali AB, Zhang Q, Lim YK, Fang D, Retnam L. Expression of major HDL-associated antioxidant. PON-1 is gender and regulated during inflammation. Free Rad Bio \& Me. 2003; 34: 824-829

Ameen AM, Hapipah MA, Abdul AK, Mohd NS, Salmah I. Evaluation of the antiulcer activities of Morus alba extracts in experimentally induced gastric ulcer in rats.Biomed Res. 2009; 20: 35-39.

Arabshahi-Delouee S, Urooj A. Antioxidant properties of various solvent extracts of mulberry (Morus indica L.) leaves. Food Chem. 2007; 102: 1233-1240.

Armstong D. Advanced Protocols in Oxidative Stres-Humana Press, New York. 2008

Balakrishnan CR, Goswami SL. Biochemical polymorphism in river buffalo. In Buffalo and goats in Asia, genetic diversity and its application. NM Tulloh (Ed), Proceeding of a seminar Kuala Lumpur, Malaysia. 1991; 34: 20-27.

Banfield F. Council of Scientific \& Industrial Research, The Wealth of India: A Dictionary of Indian Raw Materials and Industrial Products; Raw Materials, Ed; B. N. Sastri, Vol. 114, Issue 2950,1950; 49.

Başkaya Z. Gelişimi ve Dağılışı Bakımından Türkiye İpekböcekciliğinde Bilecik İlinin Yeri, Sorunları ve Çözüm Önerileri. Doğu Coğrafya Dergisi . 2014; 18 (30).

Boles A, Kandimalla R, Reddy PH. Dynamics of diabetes and obesity: Epidemiological perspective. Biochim. Biophys. Acta - Mol. Basis Dis. Elsevier B.V.; 2017; 1026-36.
Ceron JJ, Martínez-Subiela S. An automated spectrophotometric method for measuring canine ceruloplasmin in serum. Vet Res. 2004; 35 (6): 671-679.

Choi EM, Hwang JK. Effects of Morus alba leaf extract on the production of nitric oxide prostaglandin E2 and cytokines in RAW2647 macrophages. Fitoterapia. 2005; 76: 608613.

Curzon G, Vallet L. The prufication of human ceruloplasmin. Biochem J. 1960; 74: 279-287.

Demirel M. İnsülin Tedavisi Başlanan Diabet Hastalarında Kilo Değişimi ve Bumu Etkileyen Parametrelerin İrdelenmesi. T.C Sağlık Bakanlığı Şişli Eftal Eğitim ve Araştırma Hastanesi Aile Hekimliği Șefliği. Uz Tez. 2009; 5.

Dik B, Bas AL, Yazıhan N. The effect ofmidkine on growth factors and oxidative status in an experimental wound modelin diabetic and healthy rats. Canadian Journal of Physiology and Pharmacology. 2017; 95(5): 604-609.

Du J, He ZD, Jiang R.W, Ye WC, Xu HX, But PPH. Antiviral flavonoids from the root bark of Morus alba L. Phytochemistry. 2003; 62: 1235-1238.

Enkhmaa B, Shiwaku K, Katsube T, Kitajima K, Anuurad E, Yamasaki M. Mulberry (Morus alba L.) leaves and their major flavonol quercetin 3-(6-malonylglucoside) attenuate atherosclerotic lesion development in LDL receptordeficient mice. J Nutr. 2005; 135: 729-734.

Fleming RE, Whi IP, Gitlin JD. Introduction of ceruloplasmin gene expession in rat lung during inflammation and hyperoxida.American Journal of Physiology. 1991; 260: 68-74.

Fox PL, Mukhopadhyay C, Ehre11wald E. Structure, oxidant activity and cardiovascular mechanisms ofhuman ceruloplasmin. Life Science. 1995; 56, 21, 1749-58.

Halliwell B. Reactive oxygen species in living systems, source, biochemistry and role in human disease. American Journal of Medicine. 1991; 30, 91, 3, 14-22.

Katsube T, Imawaka N, Kawano Y, Yamazaki Y, Shiwaku $\mathbf{K}$, Yamane Y. Antioxidant flavonol glycosides in mulberry (Morus alba L.) leaves isolated based on LDL antioxidant activity. Food Chem. 2006; 97: 25-31.

Khan MA, Rahman AA, Islam S, Khandokhar P, Parvin S, Islam MB, Hossain M, Rashid M, Sadik G, Nasrin S, Mollah MN, Alam AH. A comparative study on the antioxidant activity of methanolic extracts from different parts of Morus alba L. (Moraceae). BMC Research Notes. 2013; 6: 24

Kikuchi T, Nihei M, Nagai H, Fukushi H, Tabata K, Suzuki T, Akilhisa T. Albanol A from the root bark of Morus alba L. induces apoptotic cell death in HL60 human leukemia cell line. Chem Pharm Bull. 2010; 58: 568-571.

Kim SH, Kim NJ, Choi JS, Park JC. Determination of flavonoid by HPLC and biological activities from the leaves of Cudrania tricuspidata bureau. J Korean Soc Food Sci Nutr. 1993; 22: 68-72.

Kuo CC, Liu TW, Chen LT, Shiah HS, Wu CM, Cheng YT, Pan WY, Liu JF, Chen KL, Yang YN, Chen SN, Chang JY. Combination of arsenic trioxide and BCNU synergistically triggers redox-mediated autophagic cell death in human solid tumors. Free Radic Biol Med. 2011; 51: 2195-2209.

Kurçer Z, Karaoğlu D. Deneysel Diyabet Modellerinde Alloksan ve Streptozotosin Kullanim. Turkish Journal of Endocrinology and Metabolism. 2012; 16: 34-40.

Lee YJ, Choi DH, Kim EJ, Kim HY, Kwon TO, Kang DG, 
Lee HS. Hypotensive, hypolipidemic, and vascular protective effects of Morus alba L. in rats fed an atherogenic diet. Am J Chin Med. 2011; 39: 39-52.

Mcpearson RA . Clinical Diagnosis and Management by Laboratory Method, In, Henry JB, editör, Philadelphia, W.B. Saunders Company.1996; s. 237-57

Niidome T, Takahashi K, Goto Y, Goh SM, Tanaka N, Kamei K. Mulberry leaf extract prevents amyloid betapeptide fibril formation and neurotoxicity. Neuroreport. 2007; 18: 813-816.

Niumsakul S, Bauer JA. Screening of antioxidants from medicinal plants for cardioprotective effect against doxorubicin toxicity.Basic Clin Pharmacol Toxicol. 2005; 96: 80-87.

NRC. Nutrient Requirements of Laboratory Animals, Fourth Revised Edition, National Academies Press Washington D.C.1995

Omar SIA, Amer H, Maher A. Effects of Morus alba leaves extracts on sperm count and testicular weight in experimentally streptozotocin induced diabetes male rats. 3rd Scientific Conference- College of Veterinary Medicine- University of Tikrit. 2016; 6-10.

Singab BIR, El-Beshbishy HA, Yonekawa M, Nomura T, Fukai T. Hypoglycemic effect of Egyptian Morus alba root bark extract: effect on diabetes and lipid peroxidation of streptozotocin-induced diabetic rats.J Ethnopharmacol. 2005; 100: 333-338.

Türkmen R. Klorprifos uygulanan diyabetli ratlarda likopenin antioksidan ve hipoglisemik etkilerinin araştırılması. Doktora tezi, Afyon Kocatepe Üniversitesi Sağlık Bilimleri Enstitüsü, Afyonkarahisar, 2013.

SPSS. Statistical Packages for the Social Sciences 20th ed. IBM: Chicago. 2011.

Take G, Karabay G, Yazıcı AC, Erdoğan D. Dişi Sıçanlarda Streptozotosin ile Oluşturulmuş Diyabetin Kalp Kası Üzerine Etkisinin Ultrastrüktürel Düzeyde Gösterilmesi. Uludağ Üniversitesi Tip Fakültesi Dergisi. 2004; 30(3): 199-204.

Taylor CR, Cote RJ. Immunomicroscopy: A Diagnostic Tool for the Surgical Pathologist, 2nd ed. Philadelphia, WB Saunders. 1994.

Wang CP, Wang Y, Wang X, Zhang X, Ye JF, Hu LS, Kong LD. Mulberroside a possesses potent uricosuric and nephroprotective effects in hyperuricemic mice.Planta Med. 2011; 77: 786-94.

Wattanapitayakul SK, Chularojmontri L, Herunsalee A, Charuchong-kolwongse S, Niumsakul S, Bauer JA. Screening of antioxidants from medicinal plants for cardioprotective effect against doxorubicin toxicity. Basic Clin Pharmacol Toxicol. 2005; 96: 80-87.

Yaman T, Doğan A. Streptozotosin ile Diyabet Oluşturulan Sıçanlarda Meşe Palamudu (Quercus branti Lindl.) Ekstraktların Karaciğer ve Pankreası Koruyucu Etkileri. Dicle Üniversitesi Veteriner Fakültesi Dergisi. 2016; 1(2): 7-15. 